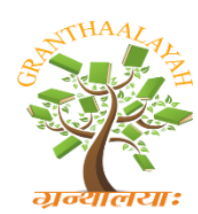

\author{
INTERNATIONAL JOURNAL OF RESEARCH - \\ GRANTHAALAYAH \\ A knowledge Repository
}

Science

\title{
EFFECT OF CORM AND CORM PIECES ON REGENERATION AND MULTIPLICATION OF ENSET (ENSETE VENTRICOSUM (WELW.) CHEESMAN)
}

\author{
Taye Buke Ashango ${ }^{* 1}$ \\ ${ }^{* 1}$ Wolaita Sodo UNIVERSITY, Wolaita Sodo, Ethiopia
}

DOI: https://doi.org/10.29121/granthaalayah.v5.i5.2017.1860

\begin{abstract}
A field study was conducted on 'enset' propagation at Humbo, Wolayta. The experiments of this study were executed with the objectives of determining size of whole corms and corm pieces for better sucker production. Five whole corm sizes $(0.75,3,7,11$ and $15 \mathrm{~kg})$, five bigger $(0.8,1.75$, $2.3,3.5$ and 4.6$)$ and three smaller $(0.2,0.3$ and $0.4 \mathrm{~kg})$ corm pieces, three corm piece positions (lower, middle and top) of horizontal cut. There were significant $(\mathrm{p}<0.01)$ differences among corms and corm pieces in the number of suckers. Whole corms with $7 \mathrm{~kg}$ gave the highest number of suckers; similarly, corm pieces with $3.5 \mathrm{~kg}$. The mean number of suckers produced ranged from 9.5-28.4 for whole corms, 3.7-38.1 for corm piece. There was no positive and significant relationship between total number of suckers and growth. Many of the other growth parameters are associated with each other. The highest sucker number was recorded using corms of $7 \mathrm{~kg}$ corm and $3.5 \mathrm{~kg}$ corm pieces.

1) Significant variations among corms and corm pieces in the number of suckers formed, with whole corms, corms with 7 and $3 \mathrm{~kg}$ weights scored the highest number of suckers. With corm pieces, those with 3.5, 4.6, and1.75 $\mathrm{kg}$ sizes scored the highest sucker numbers. Compared for whole corms, corm pieces gave the greatest overall number of suckers.

2) The size of corms and corm pieces had a significant effect on leaf width and leaf length; and sucker height, pseudostem length leaf width, leaf length and leaf number respectively.

3) The position of the corm from which pieces were taken affected their regeneration capacity. Corm pieces from the apical end of the corm were able to regenerate.
\end{abstract}

Keywords: Enset (Ensete Ventricosum) Propagation; Corms and Corm Pieces Size; Corm Position; Sun Exposure and Sucker Numbers.

Cite This Article: Taye Buke Ashango. (2017). "EFFECT OF CORM AND CORM PIECES ON REGENERATION AND MULTIPLICATION OF ENSET (ENSETE VENTRICOSUM (WELW.) CHEESMAN)." International Journal of Research - Granthaalayah, 5(5), 281-299. https://doi.org/10.29121/granthaalayah.v5.i5.2017.1860. 


\section{Introduction}

Enset (Ensete Ventricosum Welw.) is a perennial herbaceous and monocotyledonous crop, which is cultivated for its economic as well as cultural importance in Ethiopia. Due to its striking resemblance to the banana plant, it is often named as false banana but the Enset fruit is not edible. Enset is named "Koba" in none "Enset" culture area (Mahtzun and Yewelsew, 1994).

Ensete ventricosum was previously cultivated only in the south and south-western parts of Ethiopia, but recurrent droughts have led to the expansion of enset cultivation to other parts of the country. Distribution the species was mainly in Africa, but extending to India, Burma, southern China, Siam, Philippine Islands, Java and New Guinea (Cheesman, 1947).

The corm, with some basal portion of pseudostem, is utilized for propagation of enset through induction of suckers (Mulugeta et al., 1996). The traditional practice of enset propagation involves uprooting of corms and destroying the growing point to induce suckers. Corms of immature plant of about four years old are used. They scrape out the central part of the corm, until the growing bud removed. The corm is placed in shade for 2-3 days and then planted near the house at a spacing of about $0.8 \mathrm{~m} \times 0.8$. In most cases, soil, animal manure and house refuse are placed on top of the planted corm (Admasu, 2002).

When whole corm is used for sucker production without removal of apical dominance; only one sucker emerged per corm. The number of suckers per corm from $69.2 \%$ of clones producing over 40 suckers per corm (Mulugeta et al., 1992). The largest number of suckers, 35 suckers per half corms, was obtained from a three-year-old Halla clone when the mother plant was left undisturbed for one year, after removal of the apical bud (Mulugeta et al., 2002).

There have been a number of obstacles facing those engaged in the propagation of enset using traditional method. The main problems are: -slow propagation because it takes 3-5 years for the enset plant to produce corm large enough for propagation; low multiplication rate, the average number of suckers per corm per year is not more than 10/15 suckers (Mulugeta et al., 1992). This means $0-10 / 15$ suckers per corm per year. This is very low compared to potato with multiplication rate of 1:107 per 90 days (Hossain, and Vecchio, 1999) or maize multiplication rate of 53 to 61 percent. Therefore, this study was designed with the following objectives: -

- To determine the effect of corm and corm pieces on regeneration and multiplication of enset.

- To evaluate corm and corm pieces for better sucker numbers

\section{Literature Review}

\subsection{Taxonomy and Genetic Diversity}

Family Musaceae, comman name banana, order Zingiberales, and order type Basal angiospermsmonocots, consisting of 2 genera, Musa and Ensete, with about 50 species native to Africa, Asia, and Australia. Both genera are important food plants. Although enset is thicker and larger than banana, often reaching up to $12 \mathrm{~m}$ in height and more than $1 \mathrm{~m}$ in diameter, both enset and banana are herbaceous perennial monocarpic crops and habit as arborescent, cormous or 
rhizomatous perennial herbs (http://www.botany.wisc.edu, 2005). The genus Ensete was first described by Horaninow (or Horaninov) (1862) in which he created a single species, Ensete edule. However, the genus did not receive general recognition until 1947 when Cheesman revived it (Cheesman, 1947).

\subsection{Structure and Development of Enset}

\subsubsection{Structure of Enset}

The underground part consists of an adventitious root system and an underground-stem structure known as corm (Almaz, 2001). A corm is a modified stem whose central axis has become short and compact. It differs from the true bulbs in that the dominant corm is solid stem structure with nodes and internodes. It contains a good supply of storage materials. Corms are produced by certain monocots also such as banana.

\subsubsection{Growth and development of Enset}

The development of enset seedlings involves a regeneration and growth of the meristematic tissues. Eventually, individual plantlets develop their own adventitious roots for normal water and food uptake, at the same time emerging as adventitious shoots above ground and developing leaf and other structures. Each plantlet produced by such means is genetically identical with the plant from which it came, thus known clones persisting at various enset-growing regions. This type of vegetative propagation is important because it permits large-scale multiplication of individual plant into as many separate plants, as the size of the mother enset plant will permit (Makiso, 1980).

In general, small corms, called cormels, develop just above the mother corm. These, in turn, are separated from the parent plant and, when planted in a new location, develop in to new individuals (Edmond et al., 1975). These suckers are usually allowed to grow for one year before transplanting, although they may be transplanted sooner or even left for a second year if the farmer has excess planting material (Steven et al., 1997).

\subsection{Ecology of Enset}

Ensete ventricosum occurs at altitudes from 1500-3100masl. But scattered plants can also be found at lower altitudes (1100-3100 masl). For optimum growth, the plant requires an average rainfall of $1100-1500 \mathrm{~mm}$ per year and a mean temperature of $16-20{ }^{\circ} \mathrm{C}$. It grows well in most soil types, provided they are sufficiently fertile and well drained. The ideal soils are moderately acidic to alkaline (pH 5.6 to 7.3 ) with $2-3 \%$ organic matter (Bezuneh and Feleke, 1966).

\subsection{Vegetative propagation of Enset}

For propagation farmers using corm, a tissue found in the underground central part of the plant, although sexual has been reported in a few cases, effect vegetative propagation. The corm of a two-year-old plant is cut the pseudostem at approximately $10 \mathrm{~cm}$ above the ground, then be exposed to sunlight for a period of two days and subsequently buried again in the soil after 
removal of the apical meristem area, located at the central part of the corm. After 2-3 months, new suckers will emerge (Admasu, 2002).

In order to produce suckers, about $66 \%$ of the sample farmers reported that they buried quarter of a corm into the soil. Whereas about $32 \%$ of the sample farmers use half corm as a method of enset propagation. The rest use the combination of both methods (2.6\%) (Million et al., 20003). All sample farmers in Kucha area practice vegetative propagation method in enset cultivation. Farmers use enset corm, underground stem for sucker production. About $95 \%$ of sample farmers practice half corm for sucker production while only $5 \%$ of them use whole corm (Endale et al., 2003).

Moreover, failure of sucker to emerge was higher in the case of whole corm. About $25 \%, 15 \%$ and $8 \%$ failure of sucker emergence was recorded from whole, quarter and half corms, respectively. Emergence rate was better in case of half corm. Failure in emergence of suckers from whole corm may be due to complete removal of dormant buds since they are tightly covered by layers of leaf sheaths (pseudostem) and cannot be clearly seen. In the case of quarter corm, failure of suckers to emerge could be the result of more frequent rotting (Mulugeta et al., 1992).

Number of shoots produced per corm varied between 20 and 120 plants. Large variation within and between various sizes of corm pieces was also observed. Field reports indicate that from 20200 shoots can be initiated from a single corm (Bezuneh \& Feleke, 1966; Zippel \& Alemu, 1995). The fewer number of shoots obtained may be related to the small size of corms or the very young age of the mother plants that were used in the study; farmers in Ethiopia normally use 4-6 year old enset plants for propagation. Study by Bizuayehu (2002) show that rate of multiplication is dependent on the size or age of corms used; in general, large and/or old corms produced greater callus mass, more shoots and sustained a more vigorous shoot growth than smaller and younger corms.

Suckers are usually produced from two to four-year old corms (10 to $20 \mathrm{~cm}$ in diameter) and the true stem. The mother corm pieces may be a whole corm or some portion of it. The mother corm pieces are usually planted in a nursery, often with manure, where they can receive extra care. Suckers are also formed from plants left in situ with the pseudostem and apical bud removed. It is common for a farmer to have 5 to 15 mother corm pieces each year. Usually suckers from 20 to 100 suckers form per corm pieces (Steven et al., 1197). According to Bizuayehu (2002) effect of age/size of enset corm on multiplication rate resulted in that whole corm of 2-3 year old gave higher shoots (33 per corm) than one year old corm (19 per corm) and also half corm pieces gave higher number than others.

When whole corm is used for sucker production without removal of apical dominance, only one sucker emerged per corm. To produce suckers, apical dominance should be removed by injuring the apical bud. In enset, true stem stays short until flower initiation. This true stem grows upward within pseudostem to come out of the layers of leaf sheaths upon maturity. Thus dormant buds are initiated to grow into suckers by cutting a portion of true stem to avoid apical dominance (Mulugeta et al., 1992). 
A whole corm is or it is longitudinal split into two or four parts through the apex and each part is planted separately. The largest number of suckers, 35 suckers per half corms, was obtained from a three-year-old Halla clone when the mother plant was left undisturbed for one year, after removal of the apical bud (Mulugeta et al, 2002). Some enset growers use a mother corm four to six old (Bezuneh and Feleke 1966), While others use two to three years old plants to produce suckers under mid-altitude Ethiopia conditions it was found that two to three years old mother plants of Hall'a clone gave better suckers and growth (Mulugeta et al., 1999) cited by Mulugeta (2003).

Three corm types: - whole, halved and quarter corms were used and halved and quartered mother corms when transferred to new planting holes three month after removal of apical buds, produces fewer suckers on the other hand the halved corms when uprooted and replanted immediately after removal of apical buds or not uprooted from their original growing sites, gave earlier differentiation of buds and produced more suckers. Therefore, halved corms uprooted and immediately replanted or left in situ can be used to produce more suckers with better growth (Mulugeta et al., 2002).

The number suckers obtained from the whole corm was far below what farmers get. The farmers around Areka research center, Wolayta, use split corm for propagation and do not use whole corm for sucker production. Farmers in Kambata-Hadiya and Chebo-Gurage do use whole corm usually get 60 -100 suckers from one parent whole corm. Considering the number of suckers per corm, there was no advantage of one method over the other. In the experiment, suckers from half and quarter corms emerged earlier than those from whole corms. Early emergence resulted in better sucker growth (Mulugeta et al., 1992).

Number of suckers in many cases and most of the vegetative measurements showed no significant difference among whole and split enset corms. Even when there was a significant difference, there was no consistency. On the average 22, 76 and 102 suckers were obtained from whole corm, half corm and quarter corm, respectively (Mulugeta et al., 1992).

\section{Material and Methods}

\subsection{Description of the Study Area}

The study was conducted at Humbo Woreda, which is located in Southern Nations Nationalities and People's Regional State (SNNPRS) of Wolayta administrative zone. It is located at about $420 \mathrm{~km}$ south of Addis Ababa and 20km south to Soddo town and found at $6^{\circ} .44{ }^{\prime} \mathrm{N}$ and $37^{0}$ $45^{\circ} \mathrm{E}$. The mean annual temperature and rainfall of the study area are $20^{\circ} \mathrm{c}$ and $1100 \mathrm{~mm}$ respectively. The altitude range is $1500-2200$ masl. Crop production and livestock husbandry is an integral part of the farm activity. Enset is one of the most crops of the area and cultivated for household consumptions (MOA, CSA 2004/05).

The experiment was conducted at Bossa Wanche 'kebele' general nursery site of the Woreda. The nursery used to produce planting materials and seedlings for distribution to farmers. Among the crops that were multiplied at the site and distributed for farmers are sweet potato, banana, 
mango and avocado, vegetables and forest tree seedlings. The site is run by the Woreda Agricultural and rural developments office and was established about ten years ago.

\subsection{Treatments and design}

A series of four separate experiments were conducted to determine the effect of corm size, corm pieces and position of the corm on the number of suckers regenerated and their early growth. The experiment involving corm size consisted of five treatments, with ten replications. These were corms of with average sizes of $0.75,3,7,11$ and $15 \mathrm{~kg}$ weights. The experiments with corm pieces also consisted of five treatments with average weights $2 / 3^{\text {rd }}(4.6 \mathrm{~kg})$, half $(3.5 \mathrm{~kg}), 1 / 3^{\text {rd }}$ $(2.3 \mathrm{~kg})$, quarter $(1.75 \mathrm{~kg})$ and $1 / 8^{\text {th }}(0.8 \mathrm{~kg})$ and three smaller corm pieces of average sizes of $0.2,0.3$ and $0.4 \mathrm{~kg}$. The pieces were obtained by cutting the corm longitudinally in to two, three, four, eight etc. parts.

The effect of position of corm on propagation of enset was investigated by cutting the whole corm horizontally (transverse section) in to three parts consisting of top, middle and basal parts of equal weights; the average weight for ten pieces of each part was $2.3 \mathrm{~kg}$ but differ by their shape and appearance.

Corms of enset used for the experiment were obtained or collected from farmers. The age of plants from which corms were obtained ranged from one up to four years.

The average size (weight) range of ten replicated corms were 0.75 to $15 \mathrm{~kg}$ for whole corms, 0.8 to $4.6 \mathrm{~kg}$ for corm pieces, 0.2 to $0.4 \mathrm{~kg}$ for smaller pieces and $3.5 \mathrm{~kg}$ half corms for sun treated and $2.3 \mathrm{~kg}$ for horizontally cut corm pieces. To minimize variety influence, corms used in these experiments were all from the same clone that is locally named 'Gena'. The clone is tolerant to drought and disease, which are first important criteria in selecting enset clones (Endale et al., 2003). Corms and corm pieces were planted at one meter between rows and plants (1m by $1 \mathrm{~m}$ spacing) with plot size of $1 \mathrm{~m}^{2}$. For all the five experiments, treatments were replicated ten times and RCBD was used to assign treatments.

\subsection{Experimental Procedures}

The same cultural practices were applied such as corms and corm pieces were manured over immediately after planting, cultivated (in twenty day intervals) after planting and other management practices. Finally the shoots were harvested three months and ten days after planted (March 20, 2007).

\subsection{Observation of Shoot Regeneration and Data Collection}

Observation was made on the process of shoot regeneration on enset and then morphological changes on the corms and corm pieces were observed, such as callus. To examine the effects of corm size, size of corm pieces, the following data were collected from four randomly selected plants. 
Days to $50 \%$ shoot emergence sprouts (sprouts emerged on the surface), number of corms or corm pieces regenerated per treatment and experiment and number of shoots produced per corm or corm pieces was counted for all experiment after the full development of sprouts. Percentage of regeneration,i.e. the number of corms or corm pieces regenerated divided by the number of planted and multiplied 100. Number of suckers per corm or corm piece was counted after development (three months).

Plant height, which is the length of suckers from the ground to the tip of the longest leaf, was measured; all number of leaves per plant/sucker counted and Pseudostem height from the ground level up to the point where the bases of the leaves also recorded. Length of the leaf: - the longest leaf at the point where it starts to diverge from the pseudostem and ceases to overlap other leaves to the tip, the width of the leaf: - at the point where the leaf is widest on the longest leaf and stem /suckers circumference (girth) measured at the bases of plant and all the leaf numbers counted.

Data on regeneration and emergence were collected starting from 20 days after planting corms and corm pieces. Data on plant height, leaf number, leaf length and width, sucker height and pseudostem height were taken from four randomly selected plants for each treatment and the mean values were calculated at the end of the experiment. All data were recorded from regeneration according to the parameters.

\subsection{Data Analysis}

The mean values of each treatment with regarded to the above parameters were subjected to analysis of variance (ANOVA) using SAS statistical system. The differences among means were compared using Turkey's test.

\section{Results}

\subsection{Propagation of Enset from Whole Corms}

\subsubsection{Days to 50\% Sucker Emergence}

Suckers on damaged corms emerged after eight weeks of planting. Corms with different sizes varied non-significantly ( $\mathrm{p}>0.05$ ) in days to $50 \%$ emergence of suckers (Appendix 1). This means shoots emerged almost at equal time. However, corms with $0.75 \mathrm{~kg}$ weight achieved $50 \%$ emergence a day earlier (59 days) than other corm sizes (Table 1). On the other hand, whole corms those were undamaged and intact produced suckers after one month.

\subsubsection{Regeneration Percentage}

There was relative variation among treatments in percentage of regeneration of corms. The percentage of corms that have regenerated suckers varied between 80 and $100 \%$. Treatments with corm sizes of 7 and $11 \mathrm{~kg}$ achieved $100 \%$ regeneration. All the other treatments achieved less than $100 \%$ regeneration, the lowest $(80 \%)$ being recorded for corms with sizes of 0.75 and 3 $\mathrm{kg}$; corms with $15 \mathrm{~kg}$ weight achieved $90 \%$ regeneration. The percentage of corms regenerated 
tends to increase with the increase in size of corms up to $7 \mathrm{~kg}$; it decreased with further increase in size of corms.

\subsubsection{Number of Shoots per Corm}

There was a highly significant $(\mathrm{p}<0.001)$ variation among treatments in the mean number of suckers per corm (Appendix 1). The average number of suckers produced per corm varied between 9.5 and 28.4. The lowest mean sucker number (9.5) per corm was recorded by corms with 11 and $15 \mathrm{~kg}$ weights; the highest (28.5) was recorded by corms with $7 \mathrm{~kg}$, followed by $3 \mathrm{~kg}$ corms (22.84) (Table 1). Corms weighing $0.75 \mathrm{~kg}, 11 \mathrm{~kg}$ and $15 \mathrm{~kg}$ scored significantly lower mean shoot number per corm. Corms with intact bud tips produced only one sucker.

Table 1: The effect of corm size on the numbers and size of suckers.

\begin{tabular}{lllllllll}
\hline $\mathrm{CS}$ & $\mathrm{SN}$ & $\mathrm{SH}(\mathrm{cm})$ & PC $(\mathrm{cm})$ & PH $(\mathrm{cm})$ & LW $(\mathrm{cm})$ & LL $(\mathrm{cm})$ & $\mathrm{LN}$ & $\mathrm{DE}$ \\
\hline 0.75 & 12 & 49.46 & 6.45 & 16.45 & 15.68 & $33.03^{*}$ & 5.9 & 59 \\
3 & $22.84^{* *}$ & 42.87 & 6.37 & 15.64 & 13.11 & 27.26 & 4.7 & 60 \\
7 & $28.4^{* *}$ & 40.3 & 6.4 & 17.8 & 16.2 & 22.5 & 4.4 & 60 \\
11 & 9.6 & 48.8 & 9.2 & 18.8 & $20.4^{*}$ & 29.7 & 4.9 & 60 \\
15 & 9.5 & 50.11 & 8.46 & 18.13 & 18.24 & $31.99^{*}$ & 5.2 & 60 \\
$\mathrm{MSD}$ & 7.59 & $\mathrm{NS}$ & $\mathrm{NS}$ & $\mathrm{NS}$ & 6.54 & 9.27 & $\mathrm{NS}$ & $\mathrm{NS}$ \\
$\mathrm{MSE}$ & 4.74 & 8.6 & 2.34 & 3.75 & 4.46 & 6.35 & 1.54 & 0.75 \\
$\mathrm{CV}(\%)$ & 28.2 & 18.6 & 31.1 & 21.7 & 26.4 & 22 & 30.9 & 1.4 \\
\hline
\end{tabular}

$*$ and $* *$ Indicate significant differences at $5 \%$ and $0.1 \%$ level of probability, respectively.

Ns: - non-significant at $5 \%$.

CS- corm size; SN- sucker number, SH- sucker height, PC- pseudostem circumference, PLpseudostem length, LW- leaf width, LL- leaf length, LN- leaf number, DE- days to $50 \%$ emergence.

\subsubsection{Effect of Corm Size on Size of Suckers.}

\subsubsection{Effect on Plant Height}

Corm size had no significant $(\mathrm{p}>0.05)$ effect on mean sucker height of regenerated suckers (Appendix 1). However, there were differences among different corm sizes in mean height of suckers. The highest mean sucker height $(50.11 \mathrm{~cm})$ was scored by corms with $15 \mathrm{~kg}$ weights and the lowest value $(40.30 \mathrm{~cm}$ ) was recorded by corms weighing $7 \mathrm{~kg}$ (Table 1).

\subsubsection{Effect on Pseudostem Length}

Corm size had no significant ( $p>0.05)$ effect on mean pseudostem length of regenerated suckers (Appendix 1). However, there are differences among different corm sizes in mean pseudostem length. The highest mean pseudostem length $(18.8 \mathrm{~cm})$ was achieved by corms with $11 \mathrm{~kg}$ weight and the lowest value $(15.64 \mathrm{~cm}$ ) was recorded by corms weighing $3 \mathrm{~kg}$ (Table 1$)$. 


\subsubsection{Pseudostem Circumference}

Corm size had no significant ( $p>0.05)$ effect on mean pseudostem circumference of regenerated suckers (Appendix 1). However, there were differences among different corm sizes in mean pseudostem circumference of regenerated suckers. The highest mean pseudostem circumference $(9.2 \mathrm{~cm})$ was scored by corms with $11 \mathrm{~kg}$ weight; the lowest value $(6.37 \mathrm{~cm})$ was recorded by corms weighing $3 \mathrm{~kg}$ (Table 1).

\subsubsection{Effect on Leaf Length}

Corm size had significant ( $\mathrm{p}<0.05)$ effect on mean leaf length of regenerated suckers (Appendix 1). The highest mean leaf lengths $(33.03$ and $31.99 \mathrm{~cm})$ were scored by suckers from corms with 0.75 and $15 \mathrm{~kg}$ weights, respectively; suckers from the other sizes had performed the same (Table 1).

\subsubsection{Effect on Leaf Width}

Corm size had significant $(\mathrm{p}<0.05)$ effect on mean leaf width of regenerated suckers (Appendix 1). There were differences among different corm sizes in mean leaf width. The highest mean leaf width $(20.4 \mathrm{~cm})$ was recorded by suckers from corms with $11 \mathrm{~kg}$ weights; suckers from the other sizes scored significantly lower value (Table 1).

\subsubsection{Effect on Leaf Number}

Corm size had no significant $(\mathrm{p}>0.05)$ effect on mean leaf number per plant of regenerated suckers (Appendix 1). However, there are differences among different corm sizes in mean leaf number. The highest mean leaf number (5.9) was scored by suckers from corms with $0.75 \mathrm{~kg}$ weight; the lowest value (4.4) was recorded from corms weighing $7 \mathrm{~kg}$ (Table 1).

Correlation analysis revealed that there were relationships between corm size and number of suckers, pseudostem height, stem circumference, leaf number leaf length and width (Table 2). Number of suckers of corm was significantly $(\mathrm{p}<0.05)$ and negatively correlated with sucker height, pseudostem height pseudostem circumference leaf width and leaf length $(\mathrm{p}<0.01)$ and leaf number $(\mathrm{P}<0.05)$.

Sucker height of the plant was significantly and positively correlated with pseudostem circumference, height; leaf width, length $(\mathrm{p}<0.01$, Table 2). Pseudostem height of shoots was significantly and positively correlated with leaf width and length $(\mathrm{p}<0.01)$ and leaf number) $\mathrm{p}<$ $0.05)$. Pseudostem circumference was significantly $(\mathrm{p}<0.01)$ and positively with pseudostem height and leaf width $(\mathrm{p}<0.01)$ and leaf length and number $(\mathrm{p}<0.05)$. But leaf width and leaf length were significantly $(\mathrm{p}<0.01)$ and positively with leaf length and leaf number and leaf number respectively (Table 2 ). 


\subsection{Propagation of Enset from Corm Pieces}

\subsubsection{Time of Shoot Emergence}

Corm pieces with different sizes varied non-significantly ( $p>0.05$ ) in days to $50 \%$ emergence of shoots (Appendix 2). In all the treatments, 50\% emergence was achieved after 60 days (Table 3).

\subsubsection{Regeneration Percentage}

Percentage of corm pieces regenerated varied between 70 and $90 \%$. Corm pieces with $1.75 \mathrm{~kg}$ weights achieved the highest percentage of regeneration; those with $4.6 \mathrm{~kg}$ weights achieved the lowest. Corm pieces weighing 0.8, 2.3 and $3.5 \mathrm{~kg}$ weights achieved $80 \%$ regeneration.

For corm pieces with weights between 0.2 to $0.4 \mathrm{~kg}$, percentage of regeneration ranged between 0 and $30 \%$. Corm pieces with 0.2 and $0.3 \mathrm{~kg}$ weights failed to regenerate completely. Pieces weighing $0.4 \mathrm{~kg}$ achieved $30 \%$ regeneration. Treatments with small sized corm pieces were thus excluded from subsequent analysis.

\subsubsection{Effect of Size of Corm Piece on Sucker Number}

There was a highly significant $(\mathrm{p}<0.001)$ variation among corm pieces in mean number of suckers per corm pieces (Appendix 2). Mean sucker number per corm piece ranged between 3.7 and 38.1(Table 3). Corm pieces with $3.5 \mathrm{~kg}$ weights recorded the highest mean sucker number (38.1) per piece, followed by pieces with $1.7 \mathrm{~kg}$ and $4.6 \mathrm{~kg}$ weights. Corm pieces with $0.8 \mathrm{~kg}$ and $2.3 \mathrm{~kg}$ recorded significantly lower mean sucker number per piece with the lowest value (3.7 suckers) recorded by pieces with $0.8 \mathrm{~kg}$.

Table 2: The effect of corm pieces on sucker numbers and subsequent vegetative growth

\begin{tabular}{lllllllll}
\hline $\mathrm{CP}(\mathrm{kg})$ & $\mathrm{SN}$ & $\mathrm{SH}(\mathrm{cm})$ & $\mathrm{PC}(\mathrm{cm})$ & PL $(\mathrm{cm})$ & LW $(\mathrm{cm})$ & LL $(\mathrm{cm})$ & LN & DE(days) \\
\hline 0.8 & 3.7 & $38.3^{*}$ & 5.3 & $14.6^{*}$ & $12.5^{* *}$ & $23.7^{*}$ & 3.1 & 60 \\
1.75 & $24.5^{*}$ & 25.8 & 3.2 & 9.9 & 6 & 16 & 3.1 & 60.3 \\
2.3 & 6.3 & $40.3^{*}$ & 4.7 & $17.0^{*}$ & $13.9^{* * *}$ & $23.4^{*}$ & 3 & 60.2 \\
4.6 & $19.5^{*}$ & $33.9^{*}$ & 5.4 & 9 & $9.6^{*}$ & $24.5^{*}$ & $3.7 *$ & 60 \\
3.5 & $38.1^{* *}$ & $37.4^{*}$ & 4.5 & 10.1 & 9 & $27.3^{*}$ & 3.2 & 60.7 \\
$\mathrm{MSE}$ & 6.95 & 4.33 & 2.82 & 1.93 & 2.39 & 3.55 & 0.42 & 0.77 \\
$\mathrm{MSD}$ & 14.6 & 8.3 & $\mathrm{NS}$ & 4.5 & 3.7 & 7.9 & 0.7 & $\mathrm{NS}$ \\
$\mathrm{CV}(\%)$ & 37.5 & 12.4 & 59.9 & 16.3 & 23.9 & 15.5 & 13.1 & 4.2 \\
\hline
\end{tabular}

$*$, ** And*** Indicate significant differences at 5\%, $1 \%$ and $0.1 \%$ level of probability, NS: non-significant at 5\%, MSE-mean square error.

CP-corm pieces, SN-sucker numbers, SH-sucker height, PC- pseudostem circumference PLpseudostem length, LW-leaf width, LL-leaf length, LN-leaf number, DE-days to $50 \%$ emergence. 


\subsubsection{Effect of Size of Corm Piece on Sucker Parameters}

\subsubsection{Effect on Sucker Height}

Corm piece size had significant $(\mathrm{p}<0.05)$ effect on mean sucker height of regenerated suckers (Appendix 2). The mean height of regenerated suckers per corm piece ranged from 25.8 to 40.3 (Table 3). Significantly higher mean sucker heights $(40.3,38.3,37.4$ and $33.9 \mathrm{~cm})$ by corm pieces with $2.3,0.8,3.5$ and $4.6 \mathrm{~kg}$ weights, respectively. Significantly, lower value $(25.8 \mathrm{~cm})$ was recorded by corm piece weighing $1.75 \mathrm{~kg}$ (Table 3 ).

\subsubsection{Effect on Pseudostem Circumference}

Corm piece size had no significant $(\mathrm{p}>0.05)$ effect on mean pseudostem circumference of regenerated suckers (Appendix 2). However, there are differences among different corm pieces in mean pseudostem circumference. The highest mean pseudostem circumference $(5.4 \mathrm{~cm})$ was recorded by corm piece with $4.6 \mathrm{~kg}$ weight. The lowest value $(3.2 \mathrm{~cm})$ was recorded by corms weighing $1.75 \mathrm{~kg}$ (Table 3).

\subsubsection{Effect on Pseudostem Length}

Corm piece size had significant $(\mathrm{p}<0.05)$ effect on mean pseudostem length of regenerated suckers (Appendix 2). Mean pseudostem length of suckers per corm piece ranged from 9 to 17 (Table 3). Significantly higher mean pseudostem lengths $(17$ and $14.6 \mathrm{~cm})$ were scored by suckers from corm pieces with 2.3 and $0.8 \mathrm{~kg}$ weights, respectively. Significantly lower values $(9,9.9$ and $10.1 \mathrm{~cm})$ were recorded by corm pieces weighing $4.6,1.75$ and $3.5 \mathrm{~kg}$, respectively (Table 3).

\subsubsection{Effect on Leaf Width}

Corm piece size had significant $(\mathrm{p}<0.05)$ effect on mean leaf width of regenerated suckers (Appendix 2). Mean width of leaves per corm piece ranged from 6 to 13.9 (Table 3). Higher, mean leaf widths $(13.9,12.5$ and $9.6 \mathrm{~cm})$ were scored by suckers from corm pieces with 2.3 and 0.8 and $4.6 \mathrm{~kg}$ weights, respectively. Significantly lower values $(6$ and $9 \mathrm{~cm})$ were recorded by corm pieces weighing 1.75 and $3.5 \mathrm{~kg}$, respectively (Table 3 ).

\subsubsection{Effect on Leaf Length}

Corm piece size had significant $(\mathrm{p}<0.05)$ effect on mean leaf length of regenerated suckers (Appendix 2). Mean leaf length of suckers per corm piece ranged from 16 to 27.5 (Table 3). Significantly lower mean leaf length $(16 \mathrm{~cm})$ was scored by suckers from corm piece with 1.75 $\mathrm{kg}$ weight. Whereas other corm piece sizes revealed significantly higher leaf length (Table 3 ).

\subsubsection{Effect on Leaf Number}

Corm piece size had significant $(\mathrm{p}<0.05)$ effect on mean leaf number of regenerated suckers (Appendix 2). Mean leaf number per corm piece ranged from 3 to 3.7. Higher mean leaf number 
(3.7) was recorded by suckers from corm piece with $4.6 \mathrm{~kg}$ weight. Whereas suckers from other corm piece scored significantly lower leaf number (Table 3 ).

\section{Discussion}

\subsection{Regeneration in Enset}

\subsubsection{Patterns of Regeneration}

Two patterns of regeneration were observed in enset: single and multiple sucker formation. Corms, whose growing point was not damaged, produced single sucker. Multiple suckers were formed, from corms or corm pieces whose central growing points were removed or damaged (fig. 1). The finding shows that wounding is necessary to induce sucker formation. This finding agrees with Mulugeta et al. (1992) who reported that when whole corm is used for sucker production without removal of shoot apex, only one sucker emerged per corm. To produce suckers, bud apex should be removed or destroyed.

Wounding or destruction of the shoot apex stimulates regeneration in enset, which resulted in callus formation and took place only in the absence of intact shoot tips. Damaging the bud apex or removing it completely from the corm overcomes the controlling influence of the shoot apex. It has been suggested that wounding is a potential initiator of mitotic activity in plants. The stimulatory effect of wounding may be linked to the physical elimination of the shoot apex, which releases the cells in the sub apical region of the corm from inhibition imposed up on them by the apical meristem (Bizuayehu, 2002).

The two different patterns of plant regeneration (i.e., adventitious and auxillary) have different consequences on the products of regeneration. In general, plants regenerated through auxiliary bud method are genetically stable, as the new plants are formed from already differentiated buds and the chance that auxiliary buds undergo mutation is low (D' Amato, 1975, 1977; Morel, 1975; Murashige, 1974).

\subsubsection{Time of Regeneration}

Removing the corm's growing center also influenced time of sucker emergence. In corms and corm pieces whose growing centers were removed, suckers appeared after eight weeks. It took only 28-30 days for suckers to emerge when the growing point was undamaged. The difference in time may be explained by the differences in the origin of suckers. In intact corms, sucker's development is a continuation of the growth of the central bud. In corms where the growing center was removed, callus development was observed first and then suckers started to grow on the callus after (Fig.1 and 2).

Therefore, there are two patterns of origin of suckers; auxiliary bud development was observed in whole enset corm from preexisting dormant buds and adventitious in origin due to development of suckers following callus. Thus the origin of suckers is preexisting dormant buds that are initiated to grow into suckers by cutting a portion of true stem to avoid apical dominance (Mulugeta et al., 1992). 


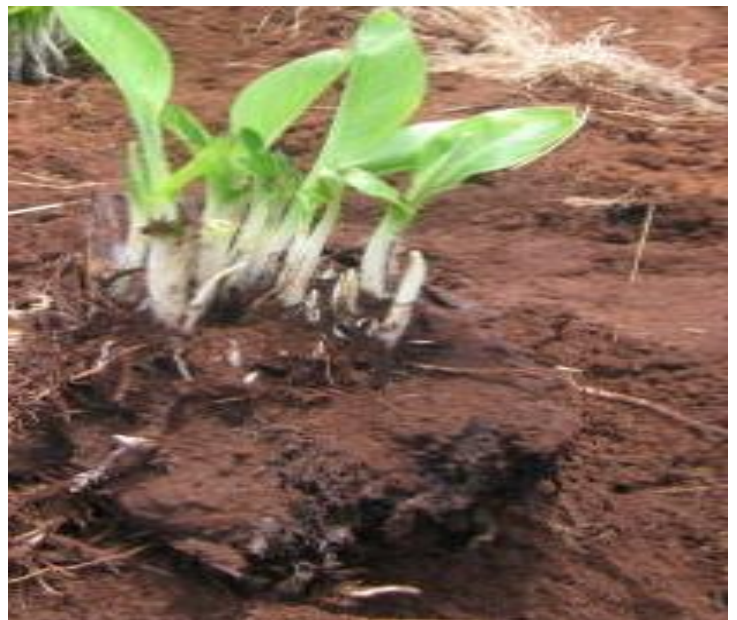

InfoBase Index IBI Factor 3.86

Figure1: Sprouts emerging after two-months (a) multiple shoots for wounded corm and corm pieces and (b) single shoot for unwounded whole corm.

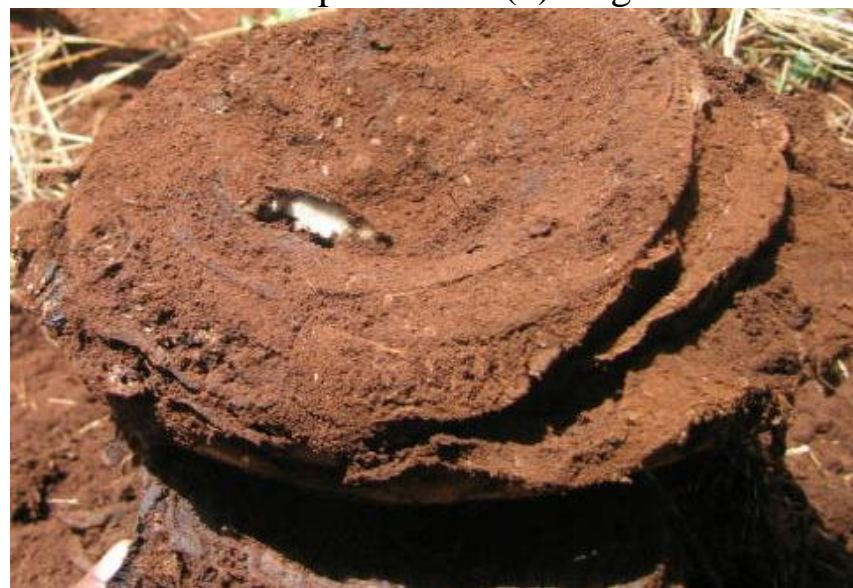

(a)

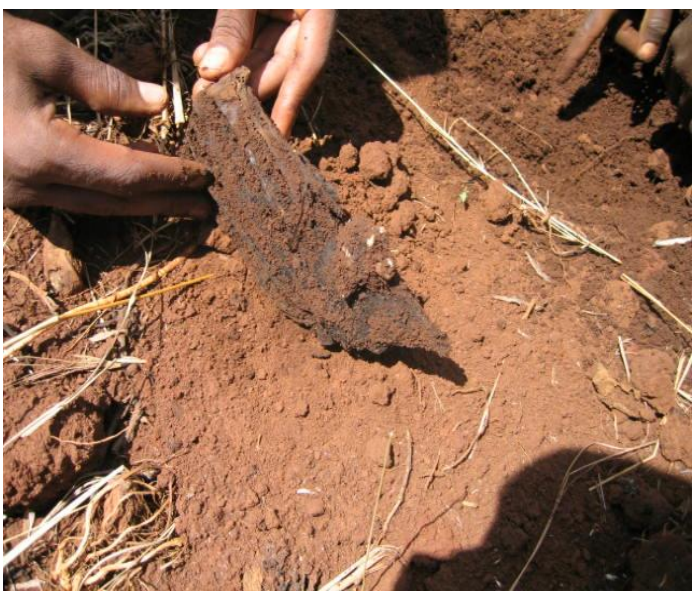

(b)

Figure 2: Appearance of swellings on corm about 30 days after removing apical bud (a) whole corm (b) corm pieces.

\subsubsection{Regeneration Percentage}

The highest (100\%) regeneration percentage of plant showed by 7 and $11 \mathrm{~kg}$ whole corms, when the sizes either increased or decreased, it decreased. In the case of corm pieces, the highest regeneration percentage (90\%) for medium and it decreased to $80 \%$ and $70 \%$ for smaller and bigger sizes, respectively. Thus regeneration rate is better in case of medium corm pieces for both corms of whole and pieces. This might be due to the absence of dormant buds of the true stem initioted dividing cell.

Percentage of regeneration in enset was influenced by size of corm or corm pieces. With corms, corm pieces and corm position, highest regeneration rates were achieved by using intermediate sizes: $7-11 \mathrm{~kg}$ (whole corms) and $1.75 \mathrm{~kg}$ (corm piece). The meristem region is located at the junction point of pseudostem and underground corm, near the soil surface (http:/www.blackwellsynergy Com/2004). The finding of this study agrees with those reported by Mulugeta et al., (1992) who also recorded higher regeneration rates using corms and corm pieces and resulted with higher regeneration rates from half corm pieces. 
The decrease in the regeneration rate with greater and smaller size may be explained due to increased incidence of rotting from large corms and corm pieces and loss of regeneration capacity of corms and corm pieces from older plants. Age of plants is known to affect regeneration capacity in many plants such as the germination behavior of seeds, for Pinus pinaster subjected differently, varied according to the age or the year of collection. This variation was more pronounced in some species than in others (http://www.edpsciences.org/, 2007).

\subsection{Effect of Size of Corms or Corm Pieces on Number of Suckers}

Number of enset suckers was affected significantly by the size of corms or corm pieces used (Appendix 1 and 2). In both whole corms and corm pieces, the highest sucker numbers were, scored by medium sized corms $(3$ and $7 \mathrm{~kg}$ ) and corm piece $(3.5 \mathrm{~kg})$. The number of sucker's decreases with increasing and decreasing size of corms or corm pieces. The finding agrees with the result of Bizuayehu (2002) who was observed that large and/ or old corms (2-3 years) produced more suckers than smaller and younger corms. Also, Mulugeta et al. (1999) cited by Mulugeta (2003) reported that corms from 2 to 3 years old mother plants gave better suckers and growth than those from 4 to 6 years old.

Different reasons can be forwarded to explain the effect of size of corms or corm pieces on the number of suckers. Size influences the amount of reserves available for regeneration. Increasing the size of the corms or corm pieces up to a certain weight, will increase the amount of reserves for cell division, callus proliferation and the size of the resulting callus which will also influence the number of buds that are initiated. As only the apical end of the corm has regeneration potential, size affects the area of the corm that has the potential for the formation of buds from which suckers develop.

\subsection{Multiplication Rate of Enset from Whole Corms and Corm Pieces}

From the above discussion the number of suckers (multiplication rate) was influenced strongly by size of corms and corm pieces. Number of shoots formed is dependent on the size of corms used for multiplication, with larger corms and corm pieces producing more shoots than smaller ones (Bizuayehu, 2002).

In this study, maximum suckers of 28.4 were achieved using whole corms. For corm pieces, the number of suckers produced was 38.1 using $3.5 \mathrm{~kg}$ or half corms, 24.5 using $1.75 \mathrm{~kg}$ or quarter corms and 19.5 using $4.6 \mathrm{~kg}$ or two third corm pieces. Cutting of the corm in to various sized pieces thus increased the number of suckers produced compared with whole corms. Thus, the number of suckers produced was more than double using half corms compared with whole corms, whereas three times more plants were obtained using quarter pieces. Bizuayeh (2002) and Mulugeta et al. (1992), also obtained higher number of suckers using half and quarter corm pieces, respectively. The use of quarter corm pieces for propagation is economical method for raising large number of plants.

In Ethiopian conditions farmers propagate enset using whole corms, half corms, quarter corms according to agroecology, cultural practice, farm size and living status of the farmers etc. In order to produce suckers, about $66 \%$ of the sample farmers use quarter corm pieces in Masha 
Wereda Shaka Zone (Million et al., 2003), but about 95\% farmers practice half corm in Kucha Wereda Gamo Gofa Zone (Endale et al., 2003). The farmers around Areka research center, Wolayta, use split corm for propagation and do not use whole corm for sucker production. Farmers in Kambata-Hadiya and Chebo-Gurage do use whole corm (Mulugeta et al., 1992).

In this study, multiplication of enset was achieved using small corm pieces $(0.4 \mathrm{~kg})$ corms from plants. The use of small and young plants can shorten the time farmers wait to propagate enset. It is also economical. In addition, it indicates the possibility of using mini- set techniques in enset. However more studies are needed in this regard.

\subsection{Effect of Size of Corms or Corm Pieces on Size and Growth of Regenerated Suckers}

Mean leaf length and leaf width of regenerated suckers were affected significantly $(\mathrm{p}<0.05)$ by the size of the corm (Table 1). Similarly, mean sucker height, pseudostem length, leaf width, leaf length and leaf number of regenerated suckers were affected significantly $(\mathrm{p}<0.05)$ by the size of corm pieces (Table 2). The above facts show that growth of regenerated suckers is affected by the initial size of corms and corm pieces used for propagation. Similar results have been obtained by Mulugeta (1994 and1996).

In this study, $0.75 \mathrm{~kg}$ and $15 \mathrm{~kg}$, and $11 \mathrm{~kg}$ corms recorded highest size and growth of suckers (Table 1) and corm pieces with $2.3 \mathrm{~kg}, 3.5 \mathrm{~kg} 4.6 \mathrm{~kg}$ corm weights. Small and larger corm sizes with fewer sucker numbers performed better growth of suckers for significantly affected parameters. Therefore sucker number and significantly affected growth parameters of suckers are negatively related. The smaller the sucker numbers the better the parameters due to less competition. This is also reflected in significant and negative correlation between the number of suckers per corm or corm pieces with sucker height, pseudostem girth, plant height, leaf length and leaf number (Table 2 and 4). But in the case of corm pieces there had no consistent relationship between either corm pieces size or sucker numbers and growth parameters.

Quality of planting material obtained was better when small number of suckers is formed due to less competition for reserves. Multiplication balance between number of suckers and their size should be considered. Therefore more study, in the future to evaluate the performance of suckers from different sizes, is needed.

\section{Summary and Conclusion}

Enset is a staple and co-staple food for the people south-western part of Ethiopia. It has also a great potential as a crop for food security against famine for other parts of the country. The crop is propagated traditionally by using whole corms or corm pieces. The major problems of enset propagation using the traditional method are like slow propagation (takes $3-5$ years), low multiplication rate of 10/15 suckers per corm per year, when compared with other crops.

A study was carried out to determine the effect of size of corms $(0.75,3,7,11$ and $15 \mathrm{~kg})$ and corm pieces $(0.8,1.75,2.3,3.5$ and $4.6 \mathrm{~kg})$ weights on the number and early growth of suckers. The effect of size, were investigated by considering the time, percentage of regeneration, sucker 
numbers, plant height, pseudostem circumference, pseudostem height, leaf width, leaf length and leaf numbers.

Size of corms and corm pieces affected significantly $(p<0.05)$ percentage of regeneration, number of suckers per corm; size of corm pieces affected $(\mathrm{p}<0.01)$, sucker height, pseudostem length, leaf width, leaf length and leaf number. Size had no effect $(p>0.05)$ on pseudostem circumference and emergence days to $50 \%$. The position of the corm from which pieces were taken affected significantly their regeneration capacity.

Considering the number of suckers, highest multiplication of enset was achieved using $7 \mathrm{~kg}$ (whole corms) and $3.5 \mathrm{~kg}$ (corm piece), compared to whole corms, corm pieces $\left(1 / 2,1 / 4^{\text {th }}\right.$, and $2 / 3^{\text {rd }}$ ) the highest overall multiplication of enset. These could be recommended for maximum and economical propagation of enset. Considering the growth and size of suckers, maximum plant height, leaf number, pseudostem circumference, leaf length, leaf width and pseudostem length was achieved using $3.5 \mathrm{~kg}, 4.6 \mathrm{~kg}, 4.6 \mathrm{~kg}, 3.5 \mathrm{~kg}, 2.3 \mathrm{~kg}$ and $2.3 \mathrm{~kg}$ corm pieces, respectively. However, the influence of size on growth and performance of enset plants should be investigated farther as this study.

\section{References}

[1] Admasu Tsegaye. 2002. On indigenous production, genetic diversity and crop ecology of enset (Ensete ventricosum (Welw.) Cheesman). 198pp.

[2] Almaz Negash. 2001.Diversity and conservation of (Enset ventricosu Welw.Cheesman) and its relation to household food and livelihood security in southwestern Ethiopia. 247pp.

[3] Amato, D.1977. In: Bezuneh, T. 1980. The morphology of enset embryo in urtro culture. Ethiopia Journal of Agricultural science 2: 22-28.

[4] Baker, R.E.D., Simmonds, N.W.1953. The genus Ensete in Africa. Jmperial college of Tropical Agriculture, Trindad, kew Bullefin 8, 405-420.

[5] Bezuneh, T. 1980. The morphology of enset embryo in urtro culture. Ethiopia Journal of Agricultural science 2: 22-28.

[6] Bezuneh T. and Feleke A.1966. The production and utilization of the genus Ensete in Ethiopia. Econ. Bot. 20(1): 65-70.

[7] Bezuneh, T., Felake, A., Beyie, R.1967. The cultivation of genus Ensete in Ethiopia. Soil and crops science society of Florida 27, 133-140.

[8] Bizuayehu Tesfaye. 2002.Studies on Landrace Diversity, in vivo and vitro Regeneration of Enset (Enset Ventricosum (Welw.) Cheesman.) 125pp.

[9] Central Statistical Authority, 2004/05 (1997E.C.). The Federal Democratic Republic of Ethiopia, Agricultural sample survey.

[10] Cheesman, E.E., 1947. Classification of the bananas. The genus ensete Horan. Imperial College of Tropical Agriculture, Trinidad, Kew Bulletin 2, 98-117.

[11] Dewayne, L. 2003. Landscape Plant Propagation Workbook: Unit I. General Principles of Plant Propagation. UNVERSITY of FLORIDA (http://edis.ifas.ufl.edu/).

[12] Edmond, J.B., T. L. Senn, F. S. Andrews, and R.G. Halfacre. 1975. Fundamentals of horticulture. Tata McGraw-Hill, Inc., New Delhi.

[13] Endale Tabogie. 1997. Morphological characteirization of enset (Ensete ventricosum (Welw.) Cheesman) Clones and the association of yield with Different traits. MSc.Thesis Alemaya University of Agriculture, Alemaya, Ethiopia 89p.

[14] Endale Tobagie B. 2003. Enset production in west Shewa zone, research reports No 49 EARO. 
[15] Endale T., Million T. and Gizachew W. 2003. Enset - Based Farming System of Kucha Masha Wereda Gamo Goffa zone. Research Report No 52 published by EARO @ SNNR SARE p19-35.

[16] Ethiopian Agricultural sample Enumeration, 2001/02 (1994 E.C). Statically Report on Area and production of crops. Part 2. B. A.A. July 2003.

[17] Evans E. and Blazich F.1999. Plant Propagation by Layering: Instructions for the Home Gardener. Department of Horticultural Science p1544-1551.

[18] Hartmann H. 1997. Plant propagation: principles and practices. Third edition. 662pp.

[19] Hartmann et al. 2002. Endale T., Million T. and Gizachew W. Enset - Based Farming System of Kucha Masha Wereda Gamo Goffa zone. Research Report No 52 published by EARO @ SNNR SARE p19-35.

[20] Hicks, G.S. 1980.Patterns of organ development in plant tissue culture and the problem of organ determination. Bot Rev 46(1): 1-23.

[21] Hossain M.J., And Vecchio V., 1999. Potential of Sprout Cutting on the Growth, Yield and Multiplication Rate of Potato. Ital. J. Agron., 3, 1, 1-6 (Vol. 3, NO. 1 - January 1999).

[22] Hudson T. Harmann, Dale, E. Kester, Fred, T. Davies Robert L. Geneve, 2002. Plant propagation principles and practices. Sixth Edition.

[23] Karin, Z. and Kefale, A. 1995. Farm Africa a field guide to enset Landraces of North Omo. Ethiopia farmers Research project.

[24] Kefale, A. and Stephen, S.1991. Enset in North Omo region. Farmers Research project (FRP) by Farm Africa. Technical pamphlet No. 1, A.A.49pp.

[25] Makiso T.1980. Cultural practices studies on enset at Wolayta soddo: In: Agronomic Report 1979/80. Pub. No 60. WADU (Wolayta Agricultural Development unit) Welayita Soddo.

[26] Mahtzun, T. and Yewelsew, A. 1994. Study of Enset processing Tools in the southern Regions of Ethiopia. ${ }_{\mathrm{p}} 128$

[27] Million T Endale T., and Gizachew W. 2003. Enset - Based Farming System of Kucha Masha Wereda Gamo Goffa zone. Research Report No 52 published by EARO @ SNNR SARE p19-35.

[28] Moore, E.H. 1957. Musa and Ensete. The cultivated bananas. Bailaya 175, 189-193.

[29] Morel, G. 1975. Meristem culture techniques for the long term storage of cultivated plants 125pp.

[30] Mulugeta Diro.1994. Preliminary investigation of Ensete culture. P. 120-131. In: Proceedings of the Second National Horticultural Workshop of Ethiopia (Hearath, E. and Lemma Desalegn eds.). 1-3 Dec.1992, IAR, Addis Ababa.

[31] Mulugeta Diro.1996. Effect of propagation method and corm type on number and growth of Enset (Enset Ventricosum (Welw.) Cheesman).

[32] Mulugeta Diro.2003. In vitro propagation of Enset (Ensete ventricosum (Welw.) Cheesman). 260

[33] Mulugeta Diro, Bezuayehu Haile, and Endale Tabogie. 1996. Enset propagation research

[34] review. P. 242-249. Enset-based sustainable agriculture in Ethiopia. In: proceedings of the International workshop on Enset (Tsedeke Abate, Hiebsch, C., Brandt, S.A. and Seifu Gebremariam eds.). 13-20 December 1993, Addis Ababa, Ethiopia.

[35] Mulugeta Diro. Gebremariam S, Zelleke A.,Vanstaden J. 2002. Growth of enset (Ensete venfricosum) suckers under deferent horticultural practices.

[36] Mulugeta Diro, Endale Tabogie 1992. Enset based croping system survey in some enset growing regions.Presented a $2^{\text {nd }}$ National Horticulture Workshop.1-3 December. IAR: Addis Ababa.

[37] Murashge, T.1974. Plant propagation through tissue culture. In: Bizuayehu Tesfaye. 2002.Studies on Landrace Diversity, in vivo and vitro Regeneration of Enset (Enset Ventricosum (Welw.) Cheesman) 125pp.

[38] Pankhurst, A., 1996. Social Consequences of Enset Production. In: Tsdeke, A. Hiebsch, G., Brandt, S.A., seifu, er. (Eds.). Enset based sustainable agriculture in Ethiopia. Proceedings of the international work shop or Enset. Addis Ababa, Ethiopia, 13-20 December 1993, 00 69-80.

[39] Purseglove, J.W. 1972. Musaceae. P 343-384. In: Tropical Crops. Monocotyledons 2. Longman Group Limited. London. 
[40] Shank, A.W. 1963. Some aspects of ecology and social structure in the enset compeer in south West Ethiopia, journal of Royal Anthropological Institute 93, 72-919.

[41] Shigeta, M. 1991. Forth in situ conservation of enset (E.V Welw. Cheesmon): Toward the interpretation of indigenous agricultural science of the Ari, south egtern Ethiopia Africa studies Mino (keyoto) 10, 93107.

[42] Simmonds, 1958. Enset cultivation in the southern highlands of Ethiopia review. Tropic. (Trinidad) 35: 302-307

[43] Simmonds, N.W. 1960. Bananas. longman, London.

[44] Simmonds, 1972. In: Mulugeta Diro.2003. In vitro propagation of Enset (Ensete ventricosum (Welw.) Cheesman )

[45] Smeds, H., 1955. The ensete planting culture of eastern Sidamo, Ethiopia. Acta erographica 13, 1-39.

[46] Steven A., Brand T., Anita S., 1997. The "TREE AGAINST HUNGER" Enset-Based Agricultural Systems in Ethiopia p19-53.

[47] Terefe Belehu, Geleta Legese,Endale Tobagie and Mulugeta Diro. 1994. Sweet potato and enset propagation studies. P. 288-300. In proceedings of the second National Horticultural Workshop of Ethiopia (Heart, E. and Lemma desalegn eds.), 1-3 December 1992, IAR, Addis Abeba.

[48] Vavilov, N.T. 1951. The origin, variation, Immunity and Breeding of cultivated plants. Chronica Botanica 13(1-6): 1-364.

[49] Westphal, E., 1975 Agricultural system in Ethiopia. Center for Agricultural publication and Documentation. Wageningen, the Netherlands, 278pp.

[50] Tsedeke A.,Clifton H., StevenA., Seifu G., 1996. Enset-Based sustainable Agriculture in Ethiopia. Procedings from the International workshop on enset held in Addis Ababa, Ethiopia, 13-20 December 1993. Institute of Agricultural Research.

[51] Zippel, K. and Alemu, K. 1995. A field guide to enset landraces of North Omo. Ethopia.FRP technical Pamphlet No. 9. FARM AFRICA.

[52] (http://ww.en.wikpedia.org/,2007).

[53] (http://www.agr.gc.ca/, 2005).

[54] (http://www.agron.missouri.edu/, 2006).

[55] (http://www.answers.com/, 2003)

[56] http://www.answers.com/, 2005).

[57] (http://www.answers.com/topic/, 2007

[58] (http:/www.blackwell-synergy Com/2004).

[59] (http://www.botany.wisc.edu/, 2005).

[60] (http://www.britannica.com/, 2002).

[61] (http://www.ces.ncsu.edu/, 2007).

[62] (http://www.edpsciences.org/, 2007).

[63] (http://www.fao.org/,@ FAO, 2007

[64] http://www.herbs2000.com/flowers/, 2000).

[65] (http://www3.interscience.wiley.com/, 2007).

\section{Appendices}

Appendix Table 1: ANOVA table for suckers and growth parameters of corms.

\begin{tabular}{|l|l|l|l|l|l|}
\hline \multicolumn{1}{|c|}{ Source } & DF & \multicolumn{1}{c|}{ SS } & Mean Square & F Value & Pr > F \\
\hline Date of emergence & 4 & 4.211 & 1.053 & 1.52 & 0.22 \\
\hline Sucker No. & 4 & 2694.709 & 673.677 & 30.01 & 0.001 \\
\hline Plant height & 4 & 5.035 & 176.259 & 2.38 & 0.073 \\
\hline Pseudostem length & 4 & 53.371 & 13.343 & 0.95 & 0.451 \\
\hline
\end{tabular}




\begin{tabular}{|l|l|l|l|l|l|}
\hline Pseudostem diameter & 4 & 67.43 & 16.858 & 3.09 & 0.03 \\
\hline Leaf length & 4 & 647.02 & 161.76 & 4.68 & 0.01 \\
\hline Leaf width & 4 & 250.098 & 62.53 & 3.15 & 0.03 \\
\hline Leaf number & 4 & 11.24 & 2.81 & 1.18 & 0.34 \\
\hline
\end{tabular}

Appendix Table 2: ANOVA table for sucker numbers and growth parameters of treatments of corm pieces.

\begin{tabular}{|l|l|l|l|l|l|}
\hline \multicolumn{1}{|c|}{ Source } & DF & \multicolumn{1}{c|}{ SS } & \multicolumn{1}{c|}{ MS } & F- Value & Pr > F \\
\hline Date of emergence & 4 & 2.83 & 0.71 & 1.2 & 0.338 \\
\hline Sucker numbers & 4 & 5434.66 & 1358.66 & 28.12 & 0.001 \\
\hline Sucker height & 4 & 840.16 & 210.04 & 11.19 & 0.001 \\
\hline Pseudostem length & 4 & 296.15 & 74.04 & 19.8 & 0.001 \\
\hline Pseudostem diameter & 4 & 18.99 & 4.75 & 0.6 & 0.67 \\
\hline Leaf width & 4 & 250.01 & 62.5 & 10.9 & 0.001 \\
\hline Leaf length & 4 & 436.52 & 109.13 & 8.66 & 0.003 \\
\hline Leaf number & 4 & 1.67 & 0.42 & 2.34 & 0.088 \\
\hline
\end{tabular}

Appendix Table 3: ANOVA table for treatments of sun treated corm pieces.

\begin{tabular}{|l|l|l|l|l|l|l|}
\hline \multicolumn{1}{|c|}{ Source } & DF & \multicolumn{1}{c|}{ SS } & Mean Square & MSE & F. Value & Pr > F \\
\hline Date of emergence & 3 & 0.82 & 0.27 & 0.87 & 0.31 & 0.82 \\
\hline Sucker number & 3 & 406.84 & 135.62 & 6.73 & 2.99 & 0.05 \\
\hline Sucker height & 3 & 63.61 & 21.2 & 6.87 & 0.45 & 0.72 \\
\hline Pseudostem diameter & 3 & 3.17 & 1.06 & 0.85 & 1.46 & 0.25 \\
\hline Pseudostem height & 3 & 7.09 & 2.37 & 2.09 & 0.54 & 0.66 \\
\hline Leaf width & 3 & 10.42 & 3.47 & 1.77 & 1.11 & 0.37 \\
\hline Leaf length & 3 & 28.92 & 9.64 & 5.23 & 0.35 & 0.79 \\
\hline Leaf number & 3 & 0.87 & 0.29 & 0.57 & 0.51 & 0.68 \\
\hline
\end{tabular}

\section{Biographical Sketch}

The author, Taye Buke, was born in Sorei Hombba kebele, Boloso sorie woreda of Wolayta Zone on February 16, 1975. He attended his primary, secondary, and high school in Dubbo Catholic mission, Areka and Bodditi schools respectively until 1994. He joined Awassa College of Agriculture in 1995 and graduated with B.Sc. Degree in Plant Production and Dry Land Farming in 1999. He then served as senior expert in different positions for Office of Agriculture in Kacha Bira woreda of Kambata Tambaro zone for three years. And then he was appointed as head of Humbo woreda rural development coordination office and worked there until he joined Hawassa University for his M.Sc study. He finally joined Hawassa University, Awassa College of Agriculture in 2005 for graduate studies to specialize Horticulture.

*Corresponding author.

E-mail address: tayebuke@yahoo.com 